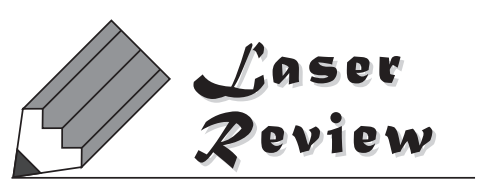

\title{
高強度レーザーを用いた宇宙物理実験
}

\author{
坂和 洋一 ${ }^{1}$, 蔵満 康浩 ${ }^{1}$, 森田 太智 ${ }^{2}$, 加藤 恒彦 ${ }^{1}$, 高部 英明 ${ }^{1,2}$ \\ '大阪大学レーザーエネルギー学研究センター（†565-0871 大阪府吹田市山田丘2-6) \\ ${ }^{2}$ 大阪大学大学院 理学研究科宇宙地球科学専攻 (T5 560-0043 大阪府豊中市待兼山町1-1)
}

\section{Laboratory Astrophysics Experiment Using High-Power Lasers}

\author{
Youichi SAKAWA, ${ }^{1}$ Yasuhiro KURAMITSU, ${ }^{1}$ Taichi MORITA, ${ }^{2}$ \\ Tsunehiko KATO, ${ }^{1}$ and Hideaki TAKABE ${ }^{1,2}$ \\ ${ }^{1}$ Institute of laser Engineering, Osaka University, 2-6 Yamadaoka, Suita, Osaka 565-0871 \\ ${ }^{2}$ Department of Earth and Space Science, Graduate Scahool of Science, Osaka University, \\ 1-1 Machikaneyama, Toyonaka, Osaka 560-0043
}

(Received October 7, 2010)

\begin{abstract}
Collisionless shocks are often observed in space and astrophysical plasmas. Large amplitude turbulent waves and energetic particles (cosmic rays) are observed in the shock environments. However, there are significant uncertainties in the physics surrounding particle acceleration by collisionless shocks. Laboratory astrophysics experiments are conducted to investigate the physical mechanisms for the generation of cosmic rays using the Gekko XII laser system at Institute of Laser Engineering, Osaka University. An electrostatic collisionless shock is observed in counter-streaming plasmas. Electron acceleration by incoherent Wakefield is studied both in particle-in-cell (PIC) simulation and laser experiment. Finally, two-dimensional PIC simulation results for the formation of a collisionless shock through the self-generated magnetic fields due to the Weibel instabilityare investigated.
\end{abstract}

Key Words: Collisionless shock, Counter-streaming plasmas, Gekko XII laser, Wakefield, Weibel instability

\section{1. はじめに}

宇宙線とは，宇宙から地球に降り注ぐ高エネルギーの 荷電粒子の総称であり，1912年にへスの気球実験により 発見された。 その主成分である陽子が組成比の約 $85 \%$ を占め, ヘリウムが約 $12 \%$, 電荷が3以上の原子核が約 $3 \%$ となっている ${ }^{1)}$. 宇宙線のエネルギースペクトルは 熱的なMaxwell分布とは大きく異なるべキ乗の分布をし ており，非熱的な粒子が宇宙を満たしている。また，こ れまでに $10^{20} \mathrm{eV}$ 超える超高エネルギー宇宙線が観測さ れているが，その起源は明らかになっていない. 観測さ れる宇宙線のエネルギースペクトルは $10^{15.5} \mathrm{eV}$ 付近で折 れ曲がっており，この部分をKneeと呼んでいる。この Knee以下のエネルギーをもつ宇宙線は, 天の川銀河内 で生成されたもの (銀河宇宙線) と考えられている ${ }^{2.3}$. またKnee以上のエネルギーの宇宙線の起源はまだ明ら かになっていないが, 活動銀河核 $(\mathrm{AGN})$ のジェットや ガンマ線バースト $(\mathrm{GRB})$ などによって加速され, 銀河 外から飛来している(銀河系外宇宙線), というモデルが 考えられている31.

銀河宇宙線の生成機構として有力視されているのが若
い超新星残骸(Supernova Remnant：SNR)における衝撃波 フェルミ加速またはDiffusive Shock Acceleration(DSA) と 呼ばれている機構である ${ }^{4,5}$. 超新星残骸とは, 星が一 生を終えて爆発(超新星爆発) した後に残される高温のガ ス球で，高速で膨張しており，数 $1000 \mathrm{~km} / \mathrm{s} て ゙$ 伝搬する 強い衝撃波を伴う。この衝撃波は, イオンーイオン衝突 の平均自由行程が衝撃波の遷移幅よりも遥かに長い, 無 衝突プラズマ中での衝撃波，無衝突衝撃波である。粒子 は衝撃波の上流や下流に存在する電磁流体波動(散乱体) によって散乱され，衝撃波を何度も横切ることができ る。上流の方が下流より流体速度が速いため, 散乱体は お互いに近づいていることになり，この散乱過程で粒子 は加速される。この衝撃波フェルミ加速は, 比較的単純 な仮定から，ベキ型エネルギースペクトルをもつ高エネ ルギー粒子の形成を説明できること，そのべキ指数が衝 撃波の詳細物理パラメータにあまり依存せずマッハ数が 大きいときは2になること, さらにこの值は多くの天体 観測で得られているスペクトルに近いこと等から, 現在 粒子加速の標準理論となっている。このメカニズムは高 エネルギー粒子の散乱体とのランダムな散乱によるもの であり, 加速の時間スケールや衝撃波の寿命・大きさを 
考慮すると, 加速の上限は $10^{15.5} \mathrm{eV}$ 程度と考えられてい $ろ^{2,3)}$.

銀河系外宇宙線の起源の1つとしてWakefield加速があ げられる ${ }^{6-8)}$. Chenは2002年にGRBで生成された強い磁 場ショックがWakefieldを励起し得ること, 相対論的に 動いているプラズマ中のWakefieldは超高エネルギー宇 宙線生成に適していることを示した ${ }^{6)}$. GRBは宇宙最大 の爆発とも言われる巨大で激しい爆発現象である.

このような, 宇宙・天体プラズマ物理学における長年 の未解決問題である高エネルギー粒子や宇宙線の加速 . 生成機構を明らかにするために, 我々は, 高出力レー ザーによる実験的な研究を行っている。本稿では, 以下 の2つのテーマについて報告する。1つ目は銀河宇宙線の 生成機構として有力視されている無衝突衝撃波による粒 子加速の解明を目指した研究, 2つ目は, 銀河系外宇宙 線の起源の1つとして考えられているWakefield加速の研 究である.1つ目の無衝突衝撃波の研究では, 高出力 レーザーによって生成された高速対向プラズマ流の相互 作用によって無衝突衝撃波を生成し，その生成機構を明 らかにするとともに, 衝撃波によるイオン加速機構の解 明を最終的な目的としている. 今回は外部磁場無しで 行った無衝突静電衝撃波の生成実験について報告す る ${ }^{9)}$. 2つ目のWakefield加速の研究では, レーザー強度 が相対論的でかつレーザーパルスの空間的スケールが電 子の慣性長よりも十分に大きな領域での2次元PICシ ミュレーションの結果 ${ }^{10)}$ と, ペタワットレーザーを用い た実験結果 ${ }^{11)}$ について述べる.

\section{2. 無衝突衝擊波の生成実験 9}

Fig. 1にターゲット照射配位を示す. $4.5 \mathrm{~mm}$ 間隔のプ ラスティック $(\mathrm{CH})$ 製平行平板型 (double-plane) ターゲッ ト $(3 \mathrm{~mm} \times 3 \mathrm{~mm}$, 厚さ $60 \mu \mathrm{m})$ の右側 $(1$ 枚目 $) \mathrm{CH}$ 平板に ターゲット垂直方向から 30 度の入射角で高出力レーザー

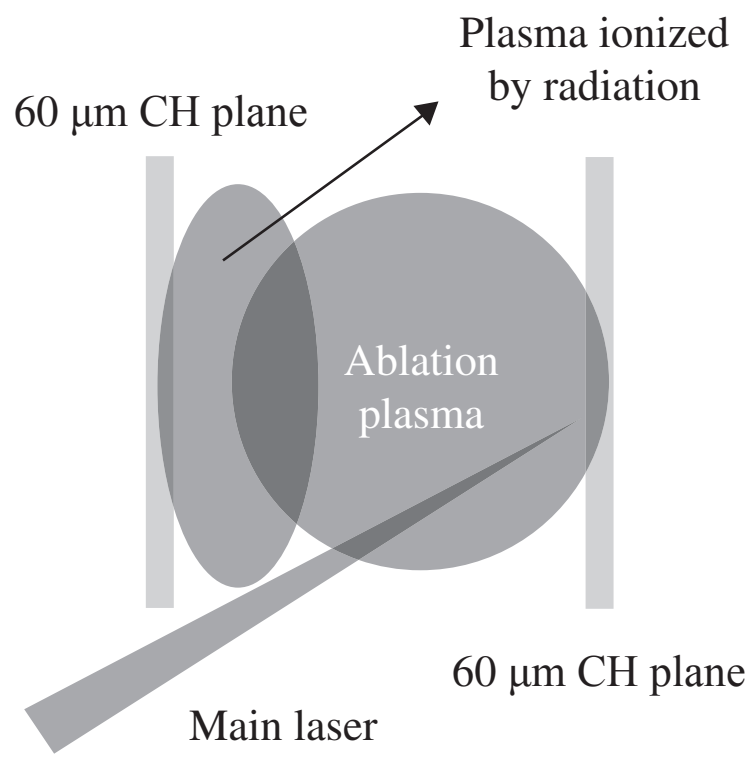

Fig. 1 Schematic of the $\mathrm{CH}$ double-plane target. The separation between two planes was $4.5 \mathrm{~mm}$.
を照射し，アブレーションプラズマを生成した。1枚目 のCHからの輻射またはプラズマ流によって左側 (2枚目) $\mathrm{CH}$ 平板のプラズマを生成し，これら高速対向プラズマ 流の無衝突相互作用により無衝突衝撃波を生成した.

実験は, 大阪大学レーザーエネルギー学研究センター の激光XII号HIPERレーザーの4ビーム (Nd:Glassレー ザー, 波長: $351 \mathrm{~nm}(3 \omega)$, パルス幅: $500 \mathrm{ps,} \mathrm{エネル}$ ギー〜120 J/ beam $\times 4$ ビーム, 総エネルギー<500 J, 強度 $\left.<10^{15} \mathrm{~W} / \mathrm{cm}^{2}\right)$ を用いて行った. HIPERレーザーは, 12本のレーザーが一方向に集められターゲットに照射さ れる。計測は, HIPERレーザーに対して垂直方向からの プローブレーザー (Nd:YAGレーザー, 波長 : $532 \mathrm{~nm}$ $(2 \omega)$, パルス幅： 〜 $14 \mathrm{~ns})$ とICCDカメラを用いたシャ ドウ計測 (SG: shadowgraph, ゲート幅 250 ps) と干渉計測 (IF:interferometer, ゲート幅 250 ps) による2次元密度測 定，ストリークカメラを用いた干渉像の時間発展(SI: streaked interferometer)を行った。また，波長 $450 \mathrm{~nm}$ の自 発光計測によるプラズマ輝度温度の測定を, ICCDカメ ラ (GOI:gate optical imager, ゲート幅1.6ns) とストリー クカメラ (SOP:streaked self-emission optical pyrometer)を 用いて行った。

Fig. 2に, SI計測 (Fig. 2 (a)) とSOP計測 (Fig. 2 (b)) の 同一ショットでの結果を示す，時間 $t=0$ はレーザー入射

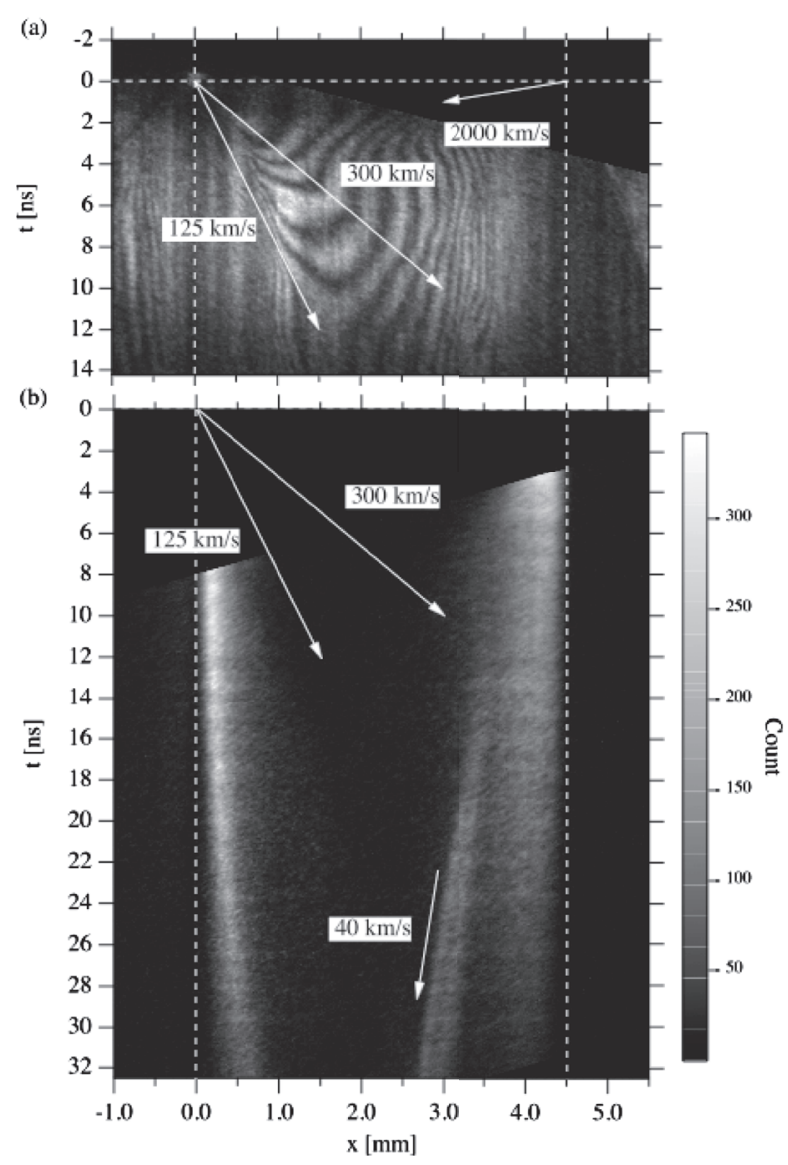

Fig. 2 (a) Streaked interferogram (SI). The horizontal and vertical dashed lines represent the main laser timing and the target positions, respectively. (b) SOP image taken on the same shot as the interferogram in (a). The laser timing corresponds to the top of the image. 
タイミングである。縦の白色破線で示したのはCH double-planeターゲットの位置で， $x=4.5 \mathrm{~mm}$ にレーザー 照射される1枚目のCH， $x=0$ に2枚目のCHが設置されて いる，2つのストリーク像は異なる特性を観測してい る. SI計測は約 $10^{18}-10^{19} \mathrm{~cm}^{-3}$ の電子密度を測定する事 ができ, SOP計測の信号強度は, 光学的に薄いプラズマ ではプラズマ密度と温度に依存する.SI計測と同時にIF 計測を行っており, 同時刻の電子密度の2次元分布を求 めている.

SI計測 (Fig. 2 (a))より，プラズマ流速を概算する事が できる。レーザーが照射された右側CHからは，レー ザー照射タイミングでのデータはないが， $x=1.5 \mathrm{~mm}$, $t=1.5 \mathrm{~ns}$ にリンジシフトが観測されていることから, 約 $2000 \mathrm{~km} / \mathrm{s}$ のプラズマ流が生成されていると思われ る. 左側CHからは，同様にフリンジシフトより125$300 \mathrm{~km} / \mathrm{s}$ のプラズマ流が生成されていると考えられる. このSI計測より求めた $125-300 \mathrm{~km} / \mathrm{s}$ のフラズマ流速を SOP計測 (Fig. 2 (b))の結果に実線で示した. SOP計測で はこのような高速プラズマは温度と密度が低く観測でき なかったが, ターゲット前面に強い発光が観測された。 ここで, 左側 $\mathrm{CH} ら の 300 \mathrm{~km} / \mathrm{s}$ の高速プラズマ流が右 側CHからのプラズマに到達する時間(約 $14 \mathrm{~ns}$ ) 近傍か ら, シャープな構造の自発光強度が増加し, 左側に向 かって伝搬しているのが分かる。これは，左側CHから の高速プラズマと右側 $\mathrm{CH}$ 近傍のプラズマとの相互作用 によって衝撃波が生成され自発光強度が増加したためで あると考えられる。この衝撃波の速度 $V_{\mathrm{s}}$ は約 $40 \mathrm{~km} / \mathrm{s} て ゙$ ある。

Fig. 3にSOP計測 (Fig. 2 (b)) から求めた自発光強度プ ロファイルの時間変化を示す。11 nsまでは右上がりの なだらかな分布をしているが, $13 \mathrm{~ns} て ゙ x 〜 3.4 \mathrm{~mm}$ 近傍に 発光強度の増加が現れ, これが時間とともに左に伝搬し ながらプロファイルが急峻になり，衝撃波が生成されて

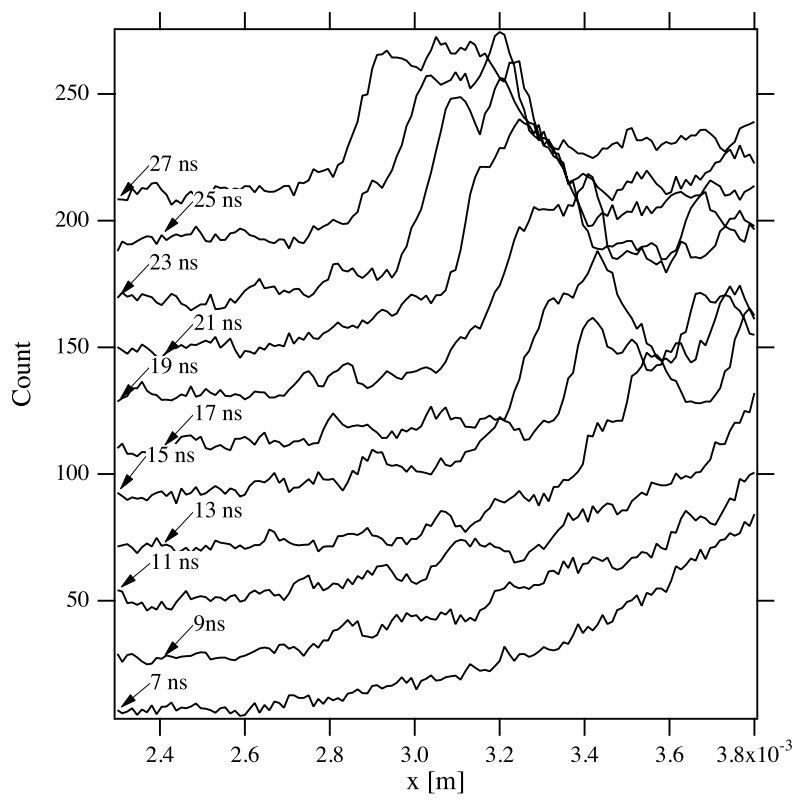

Fig. 3 Stack plot of the line profiles of the SOP image in Fig. 2 (b) from 7 to $27 \mathrm{~ns}$.
いる。この衝撃波の幅は約 $100 \mu \mathrm{m}$ である.

Figs. 4 (a) と4 (b)にそれぞれdouble-planeターゲットで の $t=25 \mathrm{~ns}$ における自発光のGOI計測とプローブ光のSG 計測の結果を示す。縦と横の破線は，それぞれターゲッ 卜表面とストリークカメラのスリットの位置を示す. $x=3$ mm近傍のFig. 3 (a)に示した衝撃波に相当する位置 において, 自発光強度の増加 (Fig. 4 (a))に加えて, 大 きな密度勾配に起因するフィラメント状の構造 (Fig. 4 (b)) が見られる. 衝撃波の中心がターゲット中 心 $(y=0)$ よりも下側にあるのは，右側ターゲットの レーザー照射位置が約 $0.5 \mathrm{~mm}$ 下となたためである.

イオンーイオン衝突平均自由行程 $\lambda_{\mathrm{ii}}$ をS Spitzerの公式 $\lambda_{\mathrm{ii}}=2 \pi \varepsilon_{0}{ }^{2} m_{\mathrm{i}}{ }^{2}<v_{\mathrm{i}}>^{4} /\left(n_{\mathrm{i}} \mathrm{Z}^{4} e^{4} \ln \Lambda\right)$ より求めた ${ }^{12)}$. ここで, $\varepsilon_{0}$ は真空中の誘電率, $m_{\mathrm{i}}$ はイオン質量, $<v_{\mathrm{i}}>$ は平均相対イ オン速度, Zeはイオン電荷量, $n_{\mathrm{i}}=n_{\mathrm{e}} / \mathrm{Z}$ はイオン密度, $\ln \Lambda=\ln \left(4 \pi \lambda_{\mathrm{D}} \varepsilon_{0} m_{\mathrm{i}}<v_{\mathrm{i}}>^{2} /\left(\mathrm{Z}^{2} e^{2}\right)\right), \lambda_{\mathrm{D}}$ はデバイ長である. $\mathrm{IF}$ 計測から求めた $n_{\mathrm{e}} \sim 10^{18} \mathrm{~cm}^{-3}, \mathrm{CH}$ プラズマの平均 $Z=3.5$, イオン質量数 $A=6.5$, 電子温度 $T_{\mathrm{e}}=100 \mathrm{eV}$ 用 いた． 右側CHからの下流プラズマが静止していると仮

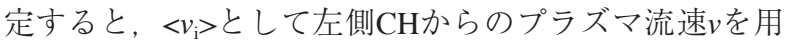
いる事になる。さらに，レーザーが右側 $\mathrm{CH}$ に照射され た $t=0$ に, 同時に左側CHからも速度 $v$ のプラズマ流が生 成されたと仮定すると， $\left\langle v_{\mathrm{i}}>=v\right.$ は時間とともに減少す る. $v=300 \mathrm{~km} / \mathrm{s}$ と $140 \mathrm{~km} / \mathrm{s}$ のプラズマ流はそれぞれ $t=11.5 \mathrm{~ns}$ と $22 \mathrm{~ns}$ に衝撃波の先端に到達し, 衝突の平均 自由行程はそれぞれ $\lambda_{\mathrm{ii}}=1.7 \mathrm{~mm}$ と $100 \mu \mathrm{m}$ となる。従っ て, 衝撃波の生成され始める初期の時間 $(t<22 \mathrm{~ns})$ では

(a)

(b)
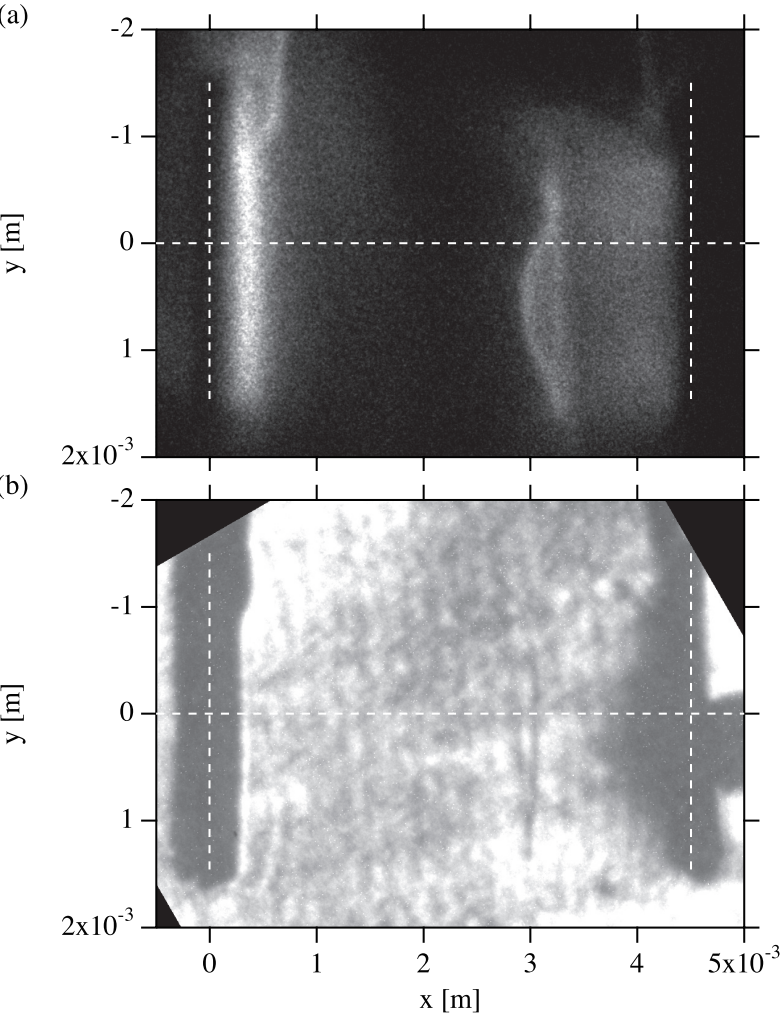

Fig. 4 (a) Self-emission (GOI) snapshot at $t=25 \mathrm{~ns}$ taken on the same shot as Fig. 2. (b) Snapshot of shadowgraphy (SG) at $t=25 \mathrm{~ns}$ taken on a different shot. 
衝突の平均自由行程が衝撃波の幅よりも長く, 無衝突相 互作用による衝撃波, 無衝突衝撃波である. 一方, 後半 の $t>22 \mathrm{~ns} て ゙ は$ 衝突の影響が大きくなる事が分かる。ま た，上記の計算では右側CHからの下流プラズマが静止 していると仮定したが，下流プラズマに流速がある場合 や，下流プラズマの音速が衝撃波速度である $40 \mathrm{~km} / \mathrm{s}$ 程 度であるとすると，その熱運動を考慮することになり， 衝突の平均自由行程は長くなり, 無衝突衝撃波の領域が 長時間 $(t \sim 28 \mathrm{~ns}$ 程度まで) 続く事になる。また, PICシ ミュレーションによって求めた遷移幅との比較から, 観 測された衝撃波は静電衝撃波であると考えられる ${ }^{13)}$.

\section{3. 非コヒーレントWakefieldによる粒子加速}

本節では，銀河系外宇宙線の起源の1つとして考えら れているWakefield加速に関する研究について報告す る.

我々は, PICシミュレーションを用いて, 衝撃波近傍 の物理現象に着目し, 2 次元プラズマに電磁波を入射す ることによって衝撃波の上流を模擬した2次元Wakefield 加速の計算を, 規格化されたレーザー強度 $a=e E_{\mathrm{L}} / m_{\mathrm{e}} c \omega_{\mathrm{L}}$ とプラズマ密度 $\omega_{\mathrm{p}} / \omega_{\mathrm{L}}$ をパラメータとして計算した。 こ こで, $e$ は電荷素量, $E_{\mathrm{L}}$ はレーザー電場， $m_{\mathrm{e}}$ は電子質量， cは光速, $\omega_{\mathrm{L}}$ はレーザー周波数, $\omega_{\mathrm{p}}$ はプラズマ周波数で ある。その結果, Fig. 5に示すように、レーザー強度が 相対論的な領域 $(a>1)$ で, なおかつレーザーパルスの 空間的スケール $\left(w_{0}\right.$ : レーザースポット径 $)$ が電子の慣性 長 $\left(c / \omega_{\mathrm{p}}\right)$ よりも十分に大きな領域(Fig. 5では $\left.w_{0} \omega_{\mathrm{p}} / c=11.9\right)$ であれば, Self-modulationとFilamentation によりWakefieldの後面が非コヒーレントとなり，電子 は加速と散乱によって非熱的に加速され，レーザー強度 (Fig. 5 (a)) とプラズマ密度 (Fig. 5 (b))によらずほぼ2の 指数を持つベキ乗のエネルギースペクトルを示した ${ }^{10)}$.

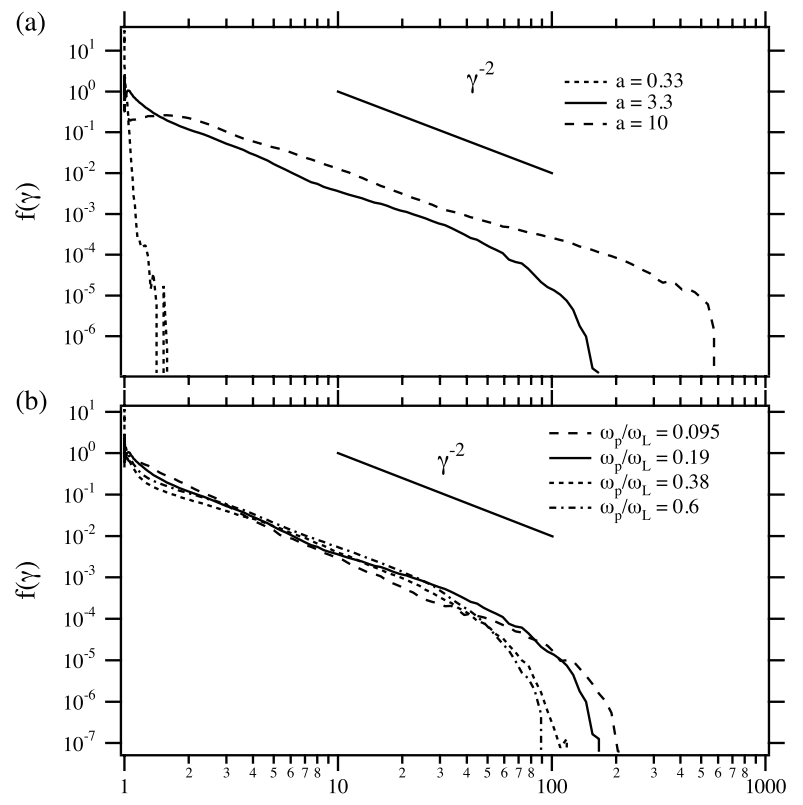

Fig. 5 (a) Intensity and (b) density dependence of the energy distribution function of the electrons.
ここで，横軸 $\gamma$ 電子のローレンツファクターであり， 縦軸のエネルギー分布関数 $f(\gamma)$ は $\int f(\gamma) d \gamma=1$ で規格化さ れている。 また, 非コヒーレント加速では, 電子のカッ トオフエネルギー(最大エネルギー) は $a$ と $\omega_{\mathrm{p}} / \omega_{\mathrm{L}}$ に加えて 拡散時間にも依存しており，時間とともにカットオフエ ネルギーが増加する ${ }^{10)}$.

このシミュレーション結果の実験的な検証も行われ た。実験は，激光XII号 (GXII) レーザーと激光ペタワッ ト (PW)レーザーを用いて行われた. Fig. 6 (a)に示すよ うに，プラスチック製のシリンダーを6本のGXIIレー ザー $\left(2 \omega ; 1 \mathrm{~ns} ;\right.$ レーザーエネルギー $E_{\mathrm{imp}}=1.9,2.0$, $2.3 \mathrm{~kJ}$ ) で爆縮することによってホロー状のプラズマを生 成した。 $3.1 \mathrm{~ns}$ 後にPWのポンプレーザー $(\omega, 700 \mathrm{fs}$, $\left.100 \mathrm{~J}, 4.3 \times 10^{18} \mathrm{~W} / \mathrm{cm}^{2}\right)$ を照射して，PWレーザーの前 方に設置した電子スペクトロメータ $(\mathrm{ESM})$ を用いて電 子のエネルギースペクトルを計測した ${ }^{14)}$. 約 $10^{19} \mathrm{~cm}^{-3}$ の バルクプラズマのエネルギー分布は， $E_{\mathrm{imp}}$ によって決ま るプラズマ密度に依存し， $E_{\mathrm{imp}}=2.3 \mathrm{~kJ}$ では, 約 $10 \mathrm{MeV}$ にピークを持つ分布を示した ${ }^{14)}$ 。一方，高エネルギー成 分に着目すると, Fig. 6 (b) に示すように, $\gamma>200$ の領 域で, 爆縮レーザーのエネルギー, すなわちプラズマ密 度によらず，ほぼ2の指数を持つべキ乗のエネルギース ペクトルを示し，Fig. 5に示したシミュレーション結果 と良く一致している ${ }^{11)}$ 。ここで, 実験結果から求めた 無次元パラメー夕は $a=1.87, \omega_{\mathrm{p}} / \omega_{\mathrm{L}}=5.21-10.6$, $w_{0} \omega_{\mathrm{p}} / c=37$ - 82 となり, 非コヒーレントなWakefield加 速の条件を満たしている。また, PICシミュレーション はmoving windowアルゴリズムを用いてパルス近傍のみ を計算しており，光速に近い速度を持つ非熱的な高エネ

(a)
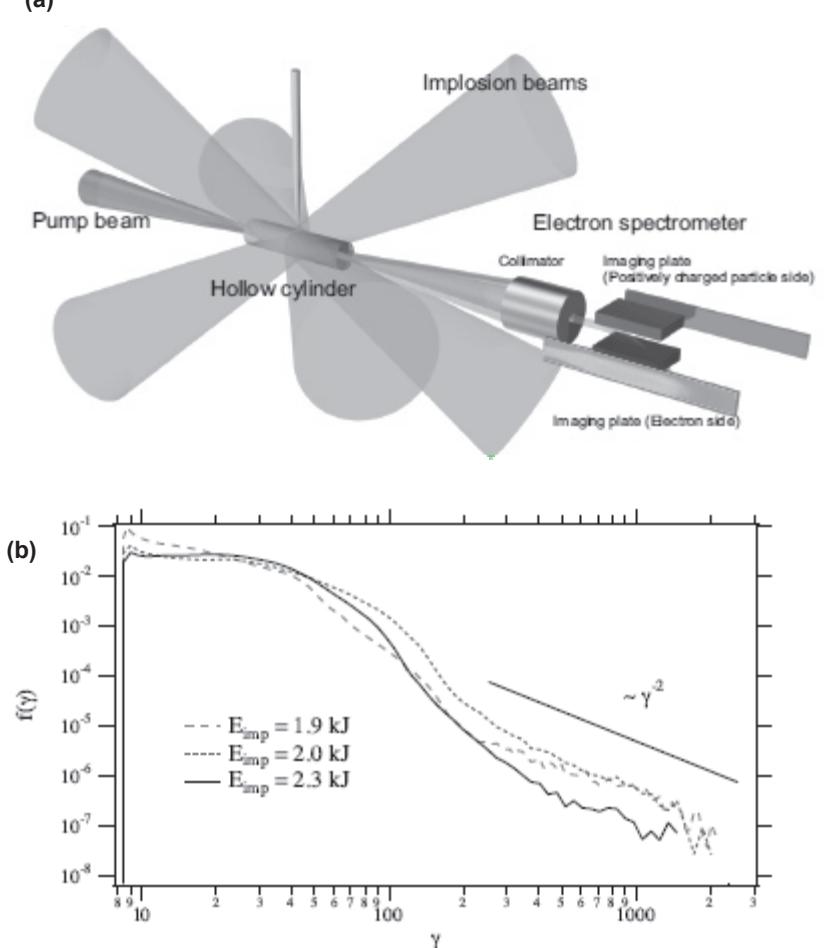

Fig. 6 (a) Schematic of the experiment. (b) Energy distribution functions of the electrons in logarithmic scales. 
ルギー粒子が主成分となるのに対し ${ }^{10)}$ ，実験では非熱的 な成分に加えて熱的なバルクプラズマも計測されるた め, ベキ乗となるエネルギー領域は 1 桁程度にとどまっ ている。.さらに実験では, PICシミュレーションに比べ てレーザーが伝搬するプラズマが大きいため, 加速電子 の最大エネルギーが大きくなっている.

星野は相対論的な宇宙衝撃波において励起される規格 化された電磁波の強度 $a$ と $\omega_{\mathrm{p}} / \omega_{\mathrm{L}}$ が, 上流バルクプラズマ のローレンツファクター $\gamma_{1}$ を用いて $, a \sim \gamma_{1}, \omega_{\mathrm{p}} / \omega_{\mathrm{L}} \sim 2 \gamma_{1}$ と表される事を示した8). AGNジェットとGRBの $\gamma_{1}$ は, それぞれ $10-20^{15)}$ と〜100 16) であると考えられており， レーザー実験はAGNジェットに近いパラメータとなっ ている.

レーザーWakefield加速の研究では，コヒーレントな 加速場による単色電子加速が注目されている ${ }^{17)}$. 宇宙線 生成機構としてのWakefield加速では, 非コヒーレント な加速場による非熱的な高エネルギー成分がどのような エネルギー分布を持っているのか, ベキ乗の分布であれ ば，その指数や加速電子の最大エネルギーがレーザーお よびプラズマパラメータに対してどのような依存性を 持っているか等, 詳細な解析が必要である。高強度レー ザー実験によって，宇宙衝撃波では直接計測する事の出 来ない非コヒーレントなWakefieldの観測を行い, 銀河 系外宇宙線の起源に対する理解が深まる事が期待され る。

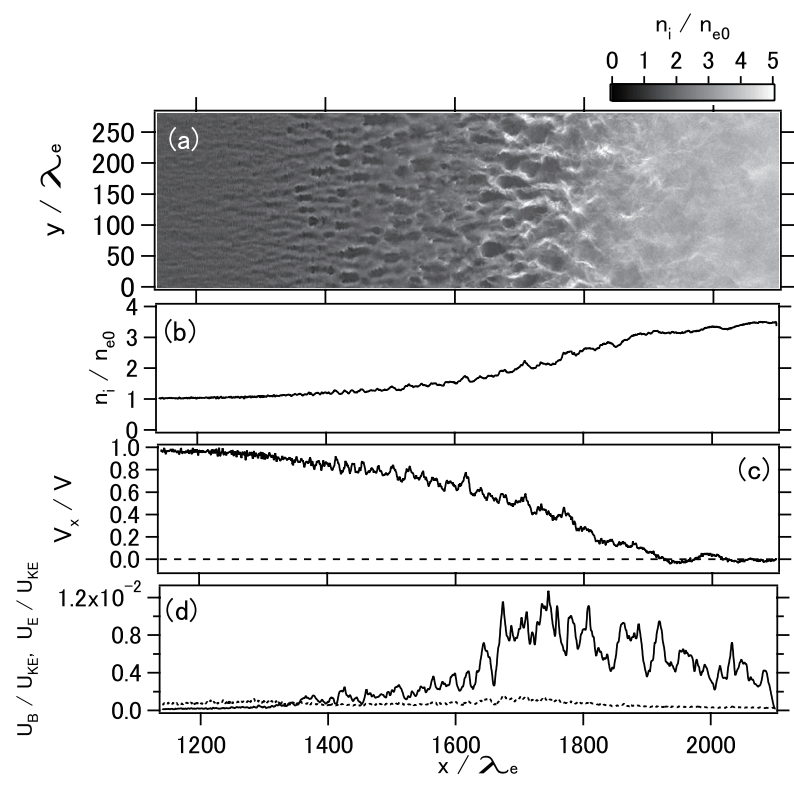

Fig. 7 (a) Number density of ions for the upstream bulk velocity of $v=0.45 \mathrm{c}$ at $\omega_{\mathrm{p}} t=2100$. The left-hand side and right-hand side are the upstream and downstream of the shock, respectively. Filamentary structure is visible in the shock transition region. Profiles of (b) the ion number density, (c) the mean velocity in the $\mathrm{x}$-direction both normalized by the respective upstream values, and (d) the energy densities of the magnetic (solid curve) and electric (dashed curve) fields both normalized by the particle bulk kinetic energy density of the upstream plasma.

\section{4. 今後の展望}

第2節では，銀河宇宙線の生成機構として有力視され ている無衝突衝撃波による粒子加速の解明を目指して 行った，高強度レーザーを用いた静電衝撃波の生成実験 の結果を示した。また，第3節では，銀河系外宇宙線の 起源の1つとして考えられている非コヒーレント Wakefield加速に関する研究結果を報告した。

今後の展望として，無衝突衝撃波生成実験では，ワイ ベル不安定性によって生成された自己生成磁場による無 衝突衝撃波(ワイベル衝撃波)生成，および，外部磁場中 の無衝突衝撃波生成の実験を計画しており，これらの研 究について以下に述べる。

\section{1 ワイベル衝撃波の生成}

加藤等は2次元粒子シミュレーションを用いて, 超新 星爆発によって発生する $10,000 \mathrm{~km} / \mathrm{s}$ 程度の高速プラズマ が二流体系でワイベル不安定性を励起し，その結果生じ る強い自己磁場によって粒子軌道が曲げられ，実効的な エネルギーの散逸が抢こり無衝突ワイベル衝撃波が形成 される事を示した ${ }^{18)}$. 2次元プラズマ粒子シミュレー ションの結果をFig. 7 と Fig. 8に示す ${ }^{18)}$ 。このシミュレー ションでは左側からの高速プラズマ流が右の壁に衝突し 反射して二流体領域を時間的に広げていく。Fig.7には, 衝撃波が形成された時刻 $\left(\omega_{\mathrm{p}} t=2100\right)$ における, イオン 数密度の二次元 $(x-y)$ 分布 (Fig. $7(\mathrm{a})), y$ 方向に平均し たイオン数密度 (Fig.7 (b)), 速度 (Fig. 7 (c)), 電場 ・ 磁場エネルギー密度 (Fig. 7 (d))の $x$ 方向分布を，Fig. 8に はイオン数密度の時間発展を示す。ここで時間は電子プ ラズマ周波数 $\left(\omega_{\mathrm{p}}\right)$ で, 長さは電子のskin $\operatorname{depth}\left(\lambda_{\mathrm{e}}=\mathrm{c} / \omega_{\mathrm{p}}\right)$ で規格化されている。強い衝撃波極限である密度上昇が 3倍(3次元では4倍)まで, 遷移領域(衝撃波面)を経て上 昇している。ワイベル不安定の線形成長，非線形構造形 成, 飽和を経て, 磁場のエネルギー密度はイオン流体の 運動エネルギー密度の1\%程度まで達している。この磁 場が左から流入するイオンの軌道をラーモア運動で乱 し，これが実質的な異常粘性の働きをし，衝撃波が形成 されていることがわかった。ワイベル衝撃波の，流速 $(v / c=0.45,0.2,0.1)$ とイオン/電子質量比 $\left(m_{\mathrm{i}} / m_{\mathrm{e}}=20\right.$, 50，100)に対するスケーリング則を求めた結果，遷移幅

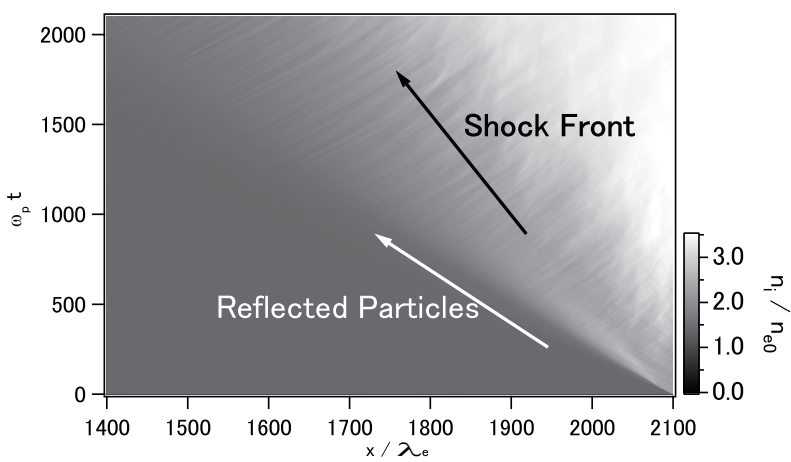

Fig. 8 Time evolution of the number density of ions $\mathrm{n}_{\mathrm{i}} / \mathrm{n}_{\mathrm{eo}}$ averaged over the $\mathrm{y}$-direction obtained from the simulation. 
はこれらパラメータに依存せずイオン慣性長の約100倍 $\left(100 c / \omega_{\mathrm{pi}}\right.$, ここで $\omega_{\mathrm{pi}}$ はイオンプラズマ周波数) となっ た ${ }^{18)}$ 。実験室プラズマにこの結果を適用した結果, $\mathrm{CH}$ プラズマで約 $1000 \mathrm{~km} / \mathrm{s}$ の流速, $10^{21} \mathrm{~cm}^{-3}$ の電子密度を実 現出来れば, 数ns程度で無衝突衝撃波が形成される事が 示唆された。

我々はこのような高速・高密度の対向プラズマ流を実 現するために，米国ローレンスリバモア研(LLNL)の NIFレーザー $(192 \text { ビーム， } 3 \omega, 1.8 \mathrm{MJ})^{\dagger 1}$ および米国口 チェスター大学の $\operatorname{OMEGA}(60$ ビーム, $3 \omega, 1 \mathrm{~ns}, 30 \mathrm{~kJ})$ とOMEGA EPのlong-pulse(4ビーム, $3 \omega, 6 \mathrm{~kJ} /$ beam) レー ザー゙を用いた実験を提案し，(NIF実験：提案者Youichi Sakawa(ILE, Osaka Univ.), Collisionless Shock Generation Mediated by Weibel Instability in Counter-Streaming Ablation Plasmas by NIF), OMEGA \& OMEGA EP実験：提案者 Hye-Sook Park (LLNL, USA), Astrophysical Collisionless Shock Generation in Laser Driven Experiments) 採択され た。今後3年間に渡って実験を行う予定である，

\section{2 外部磁場中の衝撃波の生成}

加藤等は2次元粒子シミュレーションによって, 外部 磁場のエネルギー密度と粒子の運動エネルギー密度の比 で定義される磁化パラメータが $10^{-4}$ 程度の外部磁場を印 可した場合には，無磁場の場合に比べてより短い時間で 急峻な遷移領域を持つ無衝突衝撃波が生成される事を示 した ${ }^{19)}$. これら外部磁場中の無衝突衝撃波生成実験も激 光XII号およびOMEGAとOMEGA EPレーザーを用いて 行う予定である。

\section{5. まとめ}

宇宙・天体プラズマ物理学における長年の未解決問題 である高エネルギー粒子や宇宙線の加速・生成機構を明 らかにするために, 我々は, 高出力レーザーによる実験 的な研究を行っている。本稿では, (1) 銀河宇宙線の生 成機構として有力視されている無衝突衝撃波による粒子 加速の解明を目指して行った, 外部磁場無しで高出力 レーザーによって生成された高速対向プラズマ流の相互 作用による無衝突静電衝撃波の生成実験と, (2) 銀河系 外宇宙線の起源として考えられているWakefield加速の 研究成果として，レーザー強度が相対論的な領域での2 次元PICシミュレーションの結果と, ペタワットレー ザーを用いたWakefield加速実験における非コヒーレン 卜な加速場によるベキ乗の高エネルギー電子成分の観測 結果を示した。さらに, (3)米国NIF, OMEGA, OMEGA EPレーザーを用いた実験を行う予定の, ワイベル不安 定性によって生じる自己生成磁場による無衝突衝撃波 (ワイベル衝撃波) 形成の2次元粒子シミュレーション結 果について述べた。

\footnotetext{
${ }^{\dagger 1}$ http://lasers.llnl.gov/

${ }^{\dagger 2} \mathrm{http}$ ///www.lle.rochester.edu/
}

本稿で紹介した研究の一部は日本学術振興会科学研究 費補助金基盤研究 (B) (821340172)，分野間連携による 国際拠点形成 $(H 18-21$ 年) (自然科学研究機構連携事 業)，およびレーザーエネルギー学研究センター共同利 用・共同研究からの助成のもとで行われた。またこれら の成果は, 日本, 英国, フランスの国際共同研究によっ て得られたものである。大阪大学の丹治浩樹, 青木秀憲, 井出克夫, 堂埜誠一, 中新伸彦, 田中和夫, 日本原子 力開発機構関西光科学研究所の近藤 公伯, 英国York大 学のC. Gregory, J. Waugh, N. Woosley, フランスCEAの B. Loupias, フランスLULIのA. Diziere, M. Koenig諸氏に 感謝します。

\section{参考文献}

1) C. Grupen著, 小早川恵三訳：宇宙素粒子物理学 (Springer, 2009) p.90.

2) 山崎了, 馬場 彩 : 日本物理学会誌 64 (2009) 196.

3) 星野真弘, 天野孝伸：日本物理学会誌 64 (2009) 421.

4) A. R. Bell: Monthly Notices of the Royal Astronomical Society 182 (1978) 147.

5) R. D. Blandford and J. P. Ostriker: Astrophys. J. Lett. 221 (1978) L29.

6) P. Chen, T. Tajima, and Y. Takahashi: Phys. Rev. Lett. 89 (2002) 161101.

7) Y. Lyubarsky: Astrophys. J. 652 (2006) 1297.

8) M. Hoshino: Astrophys. J. 672 (2008) 940.

9) Y. Kuramitsu, Y. Sakawa, J. N. Waugh, C. D. Gregory, T. Morita, S. Dono, H. Aoki, H. Tanji, M. Koenig, N. Woolsey, and H. Takabe: J. Phys. Conf. Ser. 244 (2010) 042009.

10) Y. Kuramitsu, Y. Sakawa, T. Kato, H. Takabe, and M. Hoshino: Astrophys. J. Lett. 682 (2008) L113.

11) Y. Kuramitsu, N. Nakanii, K. Kondo, Y. Sakawa, Y. Mori, E. Miura, K. Tsuji, K. Kimura, S. Fukumochi, M. Kashihara, T. Tanimoto, H. Nakamura, T. Ishikura, K. Takeda, M. Tampo, R. Kodama, Y. Kitagawa, K. Mima, K. A. Tanaka, M. Hoshino, and H. Takabe: Physics of Plasmas, in Press (2010); Y. Kuramitsu, N. Nakanii, K. Kondo, Y. Sakawa, Y. Mori, E. Miura, K. Tsuji, K. Kimura, S. Fukumochi, M. Kashihara, T. Tanimoto, H. Nakamura, T. Ishikura, K. Takeda, M. Tampo, R. Kodama, Y. Kitagawa, K. Mima, K. A. Tanaka, M.Hoshino, and H. Takabe: Phys. Rev. E, in Press (2010)

12) L. Spitzer: Physics of Fully Ionized Gases, 2nd ed. (New York: Interscience, 1962).

13) T. N. Kato and H. Takabe: Phys. Plasmas 17 (2010) 032114.

14) N. Nakanii, K. Kondo, Y. Kuramitsu, Y. Mori, E. Miura, K. Tsuji, K. Kimura, S. Fukumochi, M. Kashihara, T. Tanimoto, H. Nakamura, T. Ishikura, K. Takeda, M. Tampo, H. Takabe, R. Kodama, Y. Kitagawa,K. Mima, and K. A. Tanaka: Appl. Phys. Lett. 93 (2008) 081501.

15) M. C. Begelman, R. D. Blandford, and M. J. Rees: Rev. Modern Physics 56 (1984) 255.

16) B. Paczy'nski: Texas/PASCOS ' 92 , Relativistic Astrophysicsand Particle Cosmology, edited by C. W. Akerlofand M. A. Srednicki (1993), vol. 688 of New York Academy Sciences Annals.

17) S. P. D. Mangles, C. D. Murphy, Z. Najmudin, A. G. R. Thomas, J. L. Collier, A. E. Dangor, E. J. Divall, P. S. Foster, J. G. Gallacher, C. J. Hooker, et al.: Nature 431 (2004), 535; C. G. R. Geddes, Cs. Toth, J. van Tilborg, E. Esarey, C. B. Schroeder, D. Bruhwiler, C. Nieter, J. Cary, and W. P. Leemans: Nature 431 (2004) 538; J. Faure, Y. Glinec, A. Pukhov, S. Kiselev, S. Gordienko, E. Lefebvre, J.-P. Rousseau, F. Burgy, and V. Malka: Nature 431 
(2004) 541; E. Miura, K. Koyama, S. Kato, N. Saito, M. Adachi, Y. Kawada, T. Nakamura, and M. Tanimoto: Appl. Phys. Lett. 86 (2005) 251501.
18) T. N. Kato and H. Takabe: Astrophys. J. Lett. 681 (2008) L93.

19) T. N. Kato and H. Takabe: Astrophys. J. 721 (2010) 828.
フェルミ加速 (diffusive shock acceleration)

宇宙線のエネルギースペクトルは熱的なMaxwell分布 とは大きく異なるべキ乗の分布をしており， $10^{15.5} \mathrm{eVW}$ 下のエネルギーをもつ宇宙線は天の川銀河内で生成され たもの (銀河宇宙線)と考えられている. 銀河宇宙線の生 成機構として有力視されているのが超新星残骸に生成さ れる無衝突衝撃波におけるフェルミ加速，または Diffusive Shock Accelerationと呼ばれている機構である.
無衝突衝撃波とは, イオンーイオン衝突の平均自由行程 が衝撃波の遷移幅よりも遥かに長い，無衝突プラズマ中 での衝撃波である。粒子は衝撃波の上流や下流に存在す る電磁流体波動(散乱体)によって散乱され，衝撃波を何 度も横切ることができる。 上流の方が下流より流体速度 が速いため，散乱体はお互いに近づいていることにな り，この散乱過程で粒子は加速される。 (坂和 洋一)

\section{Wakefield加速 (wakefield acceleration)}

プラズマ中を大振幅の電磁波またはレーザーパルスが 通過すると, 船が水上を進む時に航跡を残すのと同じよ うに, 光の圧力 (動重力)により電子が押しのけられて, パルスの後方に強い電子プラズマ波( 航跡場, Wakefield)が励起される。 このほぼ光速で伝搬する縦波 によって荷電粒子が加速場される. これが航跡場加速
(Wakefield acceleration)である. $10^{15.5} \mathrm{eV}$ 以上のエネル ギーの宇宙線の起源はまだ明らかになっていないが，銀 河外から飛来している(銀河系外宇宙線)，と考えられて おり，その起源の1つとして，相対論的衝撃波の上流に 伝搬する大振幅の電磁波によるWakefield加速が挙げら れている. (坂和 洋一) 